\title{
パッシブ吸着建材のホルムアルデヒド放散抑制性能試験法の開発 \\ DEVELOPMENT OF TEST METHOD ABOUT SUPPRESSIVE EFFECT OF ADSORPTIVE BUILDING MATERIALS FOR FORMALDEHYDE EMITTING MATERIAL
}

\author{
安宅勇二*, 加藤信介**, 徐 長 厚***, 朱 清 宇**** \\ Yuji ATAKA, Shinsuke KATO, Jang-Hoo SEO \\ and Qingyu $Z H U$
}

In this paper, a test method for evaluating the ability of adsorptive building materials to reduce the concentration of formaldehyde is examined. The authors developed a new method that uses a small chamber to test the suppressive effect of adsorptive building material on formaldehyde-emitting materials. Two small chambers are prepared, with the formaldehyde-emitting building material placed in one chamber, and a composite building material comprised of adsorptive building material and the same kind of the formaldehyde-emitting building material in the other. The formaldehyde emission factors of the two chambers are compared, and the equivalent ventilation rate $Q_{a d s}$ is calculated. This test method enables the indoor concentration reducing performance and the suppressive performance of the adsorptive building materials to be evaluated at the same time. The tests of the suppressive effect are examined using several kinds of adsorptive building materials, and accordingly the validity of the test method is verified.

Keywords : Adsorptive Building Material, Formaldehyde, Adsorption rate, Equivalent Ventilation Rate パッシブ吸着建材、ホルムアルデヒド、吸着速度、換気量換算値

1. 序

本研究は、ホルムアルデヒド（HCHO）を室内に放散する建材に $\mathrm{HCHO}$ を吸着する能力を持つ建材（パッシブ吸着建材）をはり付け した場合の HCHO 放散抑制性能ならびに室内濃度低減性能を具体 的に測定する方法を提案し、その有用性を検討する。

シックハウス問題での $\mathrm{HCHO}$ 污染源対策が進む一方、パッシブ吸 着建材による濃度低減効果を謳った製品が市場に流通している文-5)。 最近では、(財) 日本建築センターでパッシブ吸着建材の室内空気污 染濃度低減性能に関寸る認定制度が開始されているほが6)、パッシ ブ吸着建材に関する濃度低減性能試験法の JIS 化も検討されている 丈》。しかし、それら濃度低減性能試験法が検討されているものの、 現状では統一された試験法がない文-12)。パッシブ吸着建材は蒸散支 配型建材の化学物質放散々同様、建材表面の気流性状、寸なおち物 質伝達率 $\alpha_{m}$ に大きく影響を受けることが報告されている文 12.15.16)。 污染濃度低減性能が気流性状などに大きく影響を受けることは、試 験条件の違いにより低減性能が大きく異なる可能性を意味寸る。

低減性能試験法の第一の目的は、害際に使用される時の性能を予 測できることである。すなわち、室内の条件に近い状態で試験を行 う必要がある。一般的な室内での物質伝達率は、JIS A 1901 では水 蒸気で 9 18[m/h]としている文 ${ }^{13.1 \downarrow)}$ ここの物質伝達率は、ここでは
試料面積の平均を意味しているが、気流性状だけでなく、試料面積 の大小、試料近傍の濃度分布性状などの影響も受ける。したがって、 試験時にはパッシブ吸着建材表面の物質伝達率が室内の条件に対応 するよう注意が必要である。また、濃度低減性能が雾囲気濃度の影 響を受ける可能性があるため、試験時の污染ガス濃度は、実現象に 対応させることが必要である。さらに試験片の大きさにも注意を払 う必要がある。

筆者らは物質伝達率制御型小形 Chamber（境界層型小型 Test Chamber）を用いて、定常法によるパッシブ吸着建材の HCHO 濃度 低滅性能試験を検討してきた文 ${ }^{12)}$ 。これは、実現象に対応した既知 濃度の HCHO を Test Chamberに一定濃度で供給し、給·排気濃度 $\left(C_{i}\right.$, $\left.C_{o}\right)$ を測定することによって、吸着速度 $a d s\left[\mu \mathrm{g} /\left(\mathrm{m}^{2} \mathrm{~h}\right)\right]$ および換気量 換算值 $Q_{a d s}\left[\mathrm{~m}^{3} /\left(\mathrm{hm}^{2}\right)\right]$ を求め、パッシブ吸着建材の室内 $\mathrm{HCHO}$ 濃度 低滅性能を評価する ${ }^{j ! 11}$ 。定常法は、実際の使用時に近い条件の性能 を測定するのに十分なものと考えられる。しかしながら、特に一定 濃度の污染ガスを連続供給する難しさや標準ガスが高価であるとい った欠点がある。

濃度低減建材であるパッシブ吸着建材は、污染ガス放散建材の表 面にはり付けもしくは塗布し、污染ガス放散を抑制することを目的 とするものも多い。しかし、放散面すべてを覆うことが困難な場合

\footnotetext{
* 吉野石膏(秼) 工修 (東大生研民間等共同研究員)

** 東京大学生産技術研究所 教授・工博

**** 東京大学大学院 大学院生

**** 東京大学生産技術研究所 博土研究員 - 博土 (工学)
}

Yoshino Gypsum Co., Ltd., M. Eng.

Prof., Institute of Industrial Science, Univ. of Tokyo, Dr. Eng.

Graduate Student, University of Tokyo

Institute of Industrial Science, Univ. of Tokyo, Ph. D 
もあるので、放散面全面にパッシブ吸着建材が取付けられない場合 も生じる。また、パッシブ吸着建材を使用する以上、単なるガス不透 過膜をはり付けるなどの対策とは違い、別の放散源から発生した室 内空気中の $\mathrm{HCHO}$ 濃度低減が期待されることは当然である。すなわ ち、放散を抑制する性能ならびに室内濃度低減性能を評価する試験 法が求められる。このような状況で、Test Chamber 内に一定濃度の 污染ガスを導き低減性能を試験寸る定常法とは別に、HCHO 放散建 材からの $\mathrm{HCHO}$ 放散を抑制し、さらに室内 $\mathrm{HCHO}$ 濃度を低減する 性能を同時に評価する試験法の開発が求められる。

今回、JIS A 1901 小形チャンバー法を基本とし ${ }^{14)}$. HCHO 放散抑 制性能試験法を考案し、その有効性を検討した文 17-19)。この試験法 は、パッシブ吸着建材を $\mathrm{HCHO}$ 放散建材の一部に塗布・はり合わせ るなどした場合の HCHO 放散抑制性能ならびに濃度低減性能を測 定寸るものである。本法の特徵は、1）JIS A 1901 に準じた測定法で よく、試験方法が簡便であること、2) 既存の放散試験用 Test Chamber を用いることができること、3）吸着性能を検討寸る際、吸着される 污染ガスを安定供給する手間が不要なことなどである。

本報では、(1) $\mathrm{HCHO}$ 放散抑制性能試験法の有用性、(2) 換気量 $Q$ および試験建材面積 $A$ の比 $Q / A$ を変えた場合の濃度低減性能への影 響、(3) 湿式パッシブ吸着建材(塗り壁材)への適用可能性、(4) HCHO 放散抑制性能試験と定常法による濃度低減性能試験との対态を検討 した結果を示す。また参考として、(5) 定常法試験で $Q / A$ を変えた 場合の濃度低減性能一の影響ならびに建材表面の気流性状を制御寸 るコニット文20.21) を用いた試験結果も示す。

\section{HCHO 放散抑制性能試験測定原理}

本研究では、放散抑制という用語を次のように定義する。

(a) 狭義の放散抑制 : HCHO 放散建材の放散面にパッシブ吸着建材 をはり付け、直接放散を抑制する。

(b) 広義の放散抑制：解釈を搪張した放散抑制であり、放散面から 一度気中に放散された化学物質をパッシブ吸着建材で吸着し、こ の放散面から実質的に室内に放散される化学物質の量を抑制す る効果である。

(b)の広義の放散抑制性能は、もちろん通常の室内污染濃度低隇性能 と同じである。今回提案する放散抑制性能試験は、この狭義の放散 抑制と広義の放散抑制の両者をあわせて測定寸る試験方法である。

定常的な換気のある状況下で、バッシブ吸着建材の狭義と公義の HCHO 放散抑制性能を測定寸る。2 つの小形 Chamber (Chamberl, Chamber2）を用意する。図 1 に測定システムを示寸。Chamberl に $\mathrm{HCHO}$ 放散建材を設置する。Chamber2 に HCHO 放散建材の表面の 一部（面積比 $2 / 3(67 \%)$ ) にパッシブ吸着建材をはり合わせた”複合 建材”を設置する。JIS A 1901 による測定を行い、両Chamberの HCHO 放散量（放散速度 $E F_{a}$ ） を比較し、狭義の放散抑制性能ならびに広 義の放散抑制性能（室内濃度低減性能）を評価する。

試験は複合建材のはり合わせ面から $\mathrm{HCHO}$ 放散が生じないこと、 寸なわち狭義の放散抑制性能が $100 \%$ であることを前提とする。さ らに、複合建材の HCHO 放散建材露出面（面積比 1/3 (33\%)）から 放散される $\mathrm{HCHO}$ をパッシブ吸着建材がどの程度気中から濃度低 減（広義の放散抑制）したかを評価する。そのため、パッシブ吸着 建材をはり合せた面を通して $\mathrm{HCHO}$ 放散が生ずると（狭義の放散抑

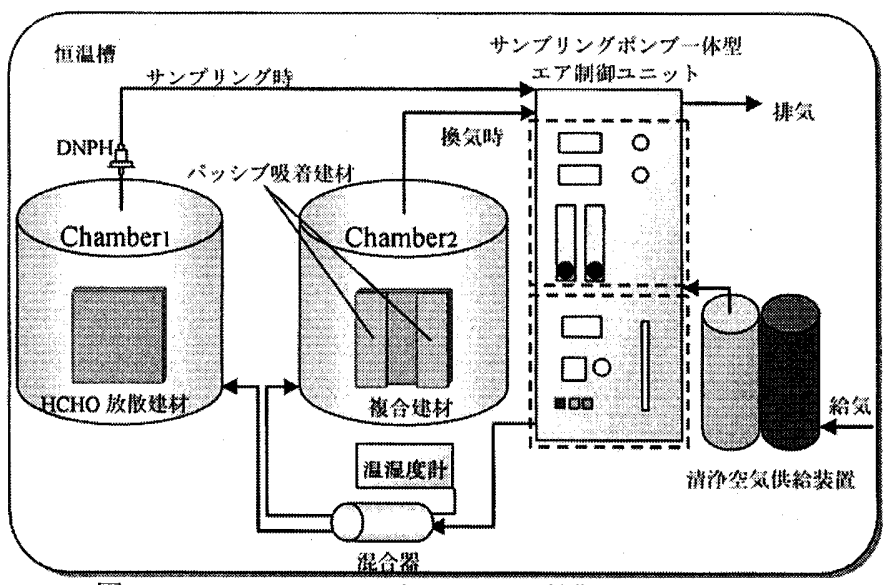

図 1 ADPAC System による HCHO 放散抑制性能試験

表 1 吸着速度 $a d s$ および換気量換算値 $Q_{a d s}$ 算出方法 ${ }^{\text {泣 2) ,3) }}$ $S_{1}=A \times E F_{a 1}=\left(C_{t 1}-C_{t b, t 1}\right) \times Q=\left(C_{t 1}-C_{t b, t 1}\right) \times n V$

$=\left(C_{t 1}-C_{t b, t 1}\right) \times q \times A=\left(C_{t 1}-C_{t b, t 1}\right) \times n / L \times A$

$S_{1,1 / 3}=\left(\frac{A}{3}\right) \times E F_{a 1,1 / 3}=\frac{A \times E F_{a 1}}{3}=\frac{\left(C_{t 1}-C_{t b, t 1}\right) \times Q}{3}$

$S_{2,1 / 3}=(A / 3) \times E F_{a 2,1 / 3}=A \times E F_{a 2}=\left(C_{t 2}-C_{t h, 12}\right) \times Q$

$=(A / 3) \times E F_{a l, 1 / 3}-(2 A / 3) \times a d s$

$a d s=1 / 2 \times\left(E F_{a 1,1 / 3}-E F_{a 2,1 / 3}\right)$

$=(Q / 2 A) \times\left\{\left(C_{t 1}-C_{t b, t 1}\right)-3\left(C_{t 2}-C_{t b, t 2}\right)\right\}$

$Q_{a d s}=\frac{a d s}{\left(C_{t 2}-C_{t b, t 2}\right)}$

$\operatorname{Sup}_{2 / 3}=\left(\frac{C_{t 1}-C_{t 2}}{C_{t 1}}\right) \times 100$

$S_{1}: \mathrm{HCHO}$ 放散量 $[\mu \mathrm{g} / \mathrm{h}]$

$S_{1.1 / 3}$ : HCHO 放散建材の 1/3(33\%)の面積から放散される HCHO 放散 量 $[\mu \mathrm{g} / \mathrm{h}]$

$E F_{a}: \mathrm{HCHO}$ 放散速度 $\left[\mu \mathrm{g} /\left(\mathrm{m}^{2} \mathrm{~h}\right)\right]$

$E F_{a .1 / 3}: \mathrm{HCHO}$ 放散建材の $1 / 3(33 \%)$ の面積から放散される $\mathrm{HCHO}$ 放 散速度 $\left[\mu \mathrm{g} /\left(\mathrm{m}^{2} \mathrm{~h}\right)\right]$

$n:$ 換気回数 $\left[\mathrm{h}^{-1}\right]$

$Q:$ 換気量 $\left[\mathrm{m}^{3} / \mathrm{h}\right]$

$V:$ Chamber 容積 $\left[\mathrm{m}^{3}\right]$

$A:$ 建材面積 $\left[\mathrm{m}^{2}\right]$

$L:$ 試料負荷率 $\left[\mathrm{m}^{2} / \mathrm{m}^{3}\right]$

$C_{t 1}$ : 経過時間 $t$ における $\mathrm{HCHO}$ 濃度 $\left[\mu \mathrm{g} / \mathrm{m}^{3}\right]$

$C_{t h, t}:$ 経過時間 $t$ に扰けるトラベルブランク $\left[\mu \mathrm{g} / \mathrm{m}^{3}\right]$

$a d s$ : パッシブ吸着建材単位面積当たりの HCHO 吸着速度 $\left[\mu \mathrm{g} /\left(\mathrm{m}^{2} \mathrm{~h}\right)\right]$

$Q_{a d s}$ : 換気量換算値 $\left[\mathrm{m}^{3} /\left(\mathrm{h} \mathrm{m}^{2}\right)\right]$

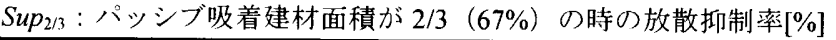

制性能のみを考えると、100\%でない場合)、その分広義の放散抑制 性能、すなわち濃度低減性能が小さく評価される。ここで、Chamber2 に設置されている複合建材の HCHO 放散建材放散面をどの程度パ ッシブ吸着建材で覆い、どの程度放散面を残寸かは、試験結果に影 響を与える。本研究では、複合建材の作製の容易さ、Test Chamber に設置した場合の対称性などを考慮し、吸着建材で覆ってない面積 が 1/3（33\%）と比較的大きい場合の検討を行う。

Chamber1 での放散建材面積の 1/3（33\%）からの HCHO 放散量が Chamber2 での HCHO 放散量と仮定し、濃度低減（広義の放散抑制） が生じない場合の Chamber2 の濃度とする。この濃度に対し、面積 
比 2/3（67\%）のパッシブ吸着建材がどの程度放散抑制性能（狭義と 広義)を有するかを測定する。なお、実際のChamber2に㧍ける $\mathrm{HCHO}$ 放散建材からの $E F_{a 2}$ は、放散面積 $A$ が $1 / 3$ に減じ、さらにパッシブ 吸着建材による HCHO吸着の影響によりChamber 内濃度が低下寸る ため放散量が大きくなり、Chamberl での $E F_{a 1}$ に比べ大きくなる傾 向を持つ义 22.23)。これは、低減性能としては安全側の性能評価にな る。

\section{3. 濃度低减性能の吸着速度および換気量換算值の算出法}

$\mathrm{HCHO}$ 放散建材を Chamberl に設置し、経過時間 $t$ における $\mathrm{HCHO}$ 放散量 $S_{1}=A \times E F_{a 1}$ は、表 1 の式（1）となる。したがって、Chamber1 の $\mathrm{HCHO}$ 放散建材の表面 1/3（33\%）加ら放散される HCHO 放散量

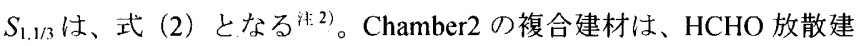
材の露出部分（面積比 1/3（33\%)）による $\mathrm{HCHO}$ 放散からパッシブ 吸着建材（面積比 $2 / 3(67 \%))$ によって污染濃度低減分が差し引か れた見掛けの $\mathrm{HCHO}$ 放散量 $S_{2.1 / 3}=(A / 3) \times E F_{a 2.1 / 3}$ が測定される（式

(3))。これより、パッシブ吸着建材の単位面積当たりの吸着速度 $a d s$ は式 (4)、換気量換算値 $Q_{a d v}$ は式（5）となる。また、放散抑制 率 $\operatorname{Sup}_{2 / 3}$ は、式（6）のように求めることができる゙渄3)。

\section{4. 試験方法}

\section{1 試験建材}

試験建材を表 2 に示寸。 $\mathrm{HCHO}$ 放散建材はPly と PB を用いた。 パッシブ吸着建材は 7 種類、遮蔽材を想定して $\mathrm{Al}$ 、比較建材 2 種類 を測定しだ永。

\subsection{HCHO 放散抑制性能試験}

\subsection{1 複合建材の作製}

HCHO 放散建材の Chamber 内濃度は、ads 算出時に試験片の面積

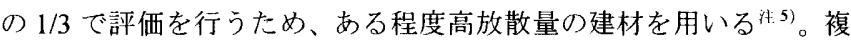
合建材の作製は、パッシブ吸着建材を $\mathrm{HCHO}$ 放散建材の一部にはり 合わせもしくは塗布する。この際、試験体面積を 3 分割し、中心部 分は $\mathrm{HCHO}$ 放散建材を露出させ（面積比 $1 / 3(33 \%))$ 、その両側に パッシブ吸着建材（面積比 $2 / 3(67 \%)$ ) をはり合わせる（図 1)。ボ 一ド類は接着剤などを使用せず、ねじ・釘などにより HCHO 放散建

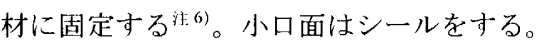

\subsection{2 試験条件}

HCHO 放散抑制性能試験は、2 20 20L 小形 Chamber ADPAC を 使用する。試験ケースを表 3 に示す。JIS A 1901 に準じ、温度 $28^{\circ} \mathrm{C}$ 、 相対湿度 $50 \%$ と寸る。初めに $\mathrm{HCHO}$ 放散建材単体での放散速度 $E F_{a}$ を確認後、複合建材を作製して試験を行う注7)。本報では HGB を用 いて $Q / A(=n / L)$ を変化させた場合の濃度低減性能一の影響を確認 後、表 3 に示寸各種建材を用いて試験を行なう。HCHO 濃度測定は JIS A 1901 に従い、分析は DNPH カートリッジによりサンプリング し $(0.167 \mathrm{~L} / \mathrm{min}, 10.0 \mathrm{~L})$ 、高速液体クロマトグラフ (HPLC) により 定量した。

\section{3 定常法による HCHO 濃度低減性能試験}

20L 小形 Chamber ADPAC を用いて、4.2 の試験に対応寸る定常法 による濃度低減性能試験を行う。試験ケースを表 4 に示す。本報で は、ADPAC Chamber 内に試験建材表面の気流が制御可能という気流

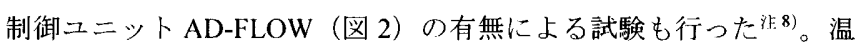

表 2 試験建材

\begin{tabular}{|c|c|c|}
\hline 種類 & 記号 & 建材名 \\
\hline \multirow{2}{*}{$\begin{array}{l}\mathrm{HCHO} \\
\text { 放散建材 }\end{array}$} & Ply & 合板 \\
\hline & PB & パーティクルボード \\
\hline \multirow{7}{*}{$\begin{array}{l}\text { パッシブ } \\
\text { 吸着建材 }\end{array}$} & $\mathrm{HGB}$ & HCHO 吸収分解せっこうボード \\
\hline & DGP & 珪藻土入りせっこうプラスター \\
\hline & WET & 湿式材料 (粘土鉣物+酵素+特殊液) \\
\hline & RW & ロックウール系建材 \\
\hline & $\mathrm{HPC}$ & 多孔質調湿セラミック建材 \\
\hline & PNT & ペンキ \\
\hline & CSB & ケイカル系調湿建材 \\
\hline 遮蔽材 & $\mathrm{Al}$ & アルミシール \\
\hline \multirow{2}{*}{ 比較建材 } & $\mathrm{RW}(\mathrm{R})$ & ロックウール系建材（通常品） \\
\hline & GB & せっこうボード（通常品） \\
\hline
\end{tabular}

表 3 HCHO 放散抑制性能試験タース $\left(28^{\circ} \mathrm{C}, 50 \% \mathrm{RH}\right)$

\begin{tabular}{lllcc}
\hline \multicolumn{1}{c}{ Case } & Chamber1 & Chamber2 & $\begin{array}{c}n \\
{\left[\mathrm{~h}^{-1}\right]}\end{array}$ & $\begin{array}{c}Q / A \\
{[\mathrm{~m} / \mathrm{h}]}\end{array}$ \\
\hline \hline SE-1-Ply & Ply & Ply & 0.5 & 0.25 \\
SE-2-PB & PB & PB & 0.5 & 0.46 \\
\hline SE-3-Ply-HGB & Ply & Ply+HGB & 0.5 & 0.25 \\
SE-4-Ply-Al & Ply & Ply+Al & 0.5 & 0.25 \\
SE-5-PB-A1 & PB & PB+Al & 0.5 & 0.23 \\
SE-6-PB-HGB1 & PB & PB+HGB & 0.5 & 0.46 \\
SE-7-PB-HGB2 & PB & PB+HGB & 0.27 & 0.25 \\
SE-8-PB-HGB3 & PB & PB+HGB & 0.5 & 0.23 \\
SE-9-PB-DGP & PB & PB+DGP & 0.5 & 0.23 \\
SE-10-PB-WET & PB & PB+WET & 0.5 & 0.23 \\
SE-11-PB-RW & PB & PB+RW & 0.5 & 0.23 \\
SE-12-PB-HPC & PB & PB+HPC & 0.5 & 0.23 \\
SE-13-PB-PNT & PB & PB+PNT & 0.5 & 0.23 \\
SE-14-PB-GB & PB & PB+GB & 0.5 & 0.23 \\
\hline
\end{tabular}

表 4 定常法試験ケース $\quad\left(28^{\circ} \mathrm{C}, 50 \% \mathrm{RH}\right)$

\begin{tabular}{llccc}
\hline \multicolumn{1}{c}{ Case } & 試料 & AD-FLOW & $n\left[\mathrm{~h}^{-1}\right]$ & $Q / A[\mathrm{~m} / \mathrm{h}]$ \\
\hline \hline SS-1-HGB1 & HGB & 有 & 0.5 & 0.46 \\
SS-2-HGB2 & HGB & 無 & 0.5 & 0.46 \\
SS-3-HGB3 & HGB & 無 & 0.5 & 0.23 \\
SS-4-DGP & DGP & 無 & 0.5 & 0.23 \\
SS-5-RW & RW & 無 & 0.5 & 0.23 \\
SS-6-HPC & HPC & 無 & 0.5 & 0.23 \\
SS-7-PNT & PNT & 無 & 0.5 & 0.23 \\
SS-8-CSB & CSB & 無 & 0.5 & 0.23 \\
SS-9-GB & GB & 無 & 0.5 & 0.23 \\
SS-10-RWR & RW(R) & 無 & 0.5 & 0.23 \\
\hline
\end{tabular}
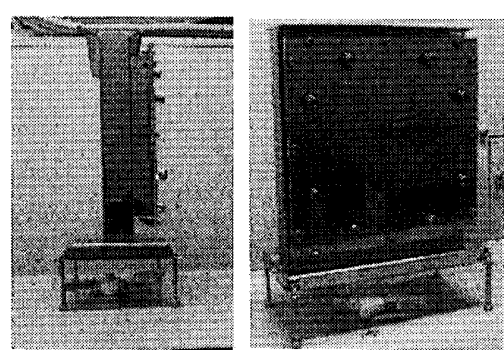

図 2 気流制御ユニットAD-FLOW 外観

度 $28^{\circ} \mathrm{C}$ 、相対湿度 $50 \% 、 n=0.5\left[\mathrm{~h}^{-1}\right] 、 Q / A(=n / L)=0.46,0.23[\mathrm{~m} / \mathrm{h}]$ とした。供給 $\mathrm{HCHO}$ 濃度 $C_{i}$ は、 $100\left[\mathrm{\mu g} / \mathrm{m}^{3}\right]$ とした。分析は 4.2 と同 様、DNPH カートリッジによりサンプリングし $(0.167 \mathrm{~L} / \mathrm{min}, 10.0 \mathrm{~L}) 、$ HPLCにより定量した。

\section{5. 結果}

\section{$5.1 \mathrm{HCHO}$ 放散抑制性能試験結果}

HCHO 放散抑制性能試験を行なった結果、一定濃度の HCHO ガス 
表 5 HCHO 放散抑制性能試験結果 $\left(28^{\circ} \mathrm{C}, 50 \% \mathrm{RH}\right)$

\begin{tabular}{|c|c|c|c|c|c|c|c|}
\hline \multirow{2}{*}{ Case } & \multicolumn{2}{|c|}{ Chamberl } & \multicolumn{2}{|c|}{ Chamber2 } & \multirow{2}{*}{$\operatorname{ads}\left[\mu \mathrm{g} /\left(\mathrm{m}^{2} \mathrm{~h}\right)\right]$} & \multirow{2}{*}{$Q_{a d s}\left[\mathrm{~m}^{3} /\left(\mathrm{hm}^{2}\right)\right]$} & \multirow{2}{*}{$\operatorname{Sup}_{2 / 3}[\%]$} \\
\hline & $C_{l}\left[\mu \mathrm{g} / \mathrm{m}^{3}\right]$ & $E F_{a l}\left[\mu \mathrm{g} /\left(\mathrm{m}^{2} \mathrm{~h}\right)\right]$ & $C_{2}\left[\mu \mathrm{g} / \mathrm{m}^{3}\right]$ & $E F_{a 2}\left[\mu \mathrm{g} /\left(\mathrm{m}^{2} \mathrm{~h}\right)\right]$ & & & \\
\hline SE-1-Ply & 400.8 & 100.2 & 519.1 & 129.8 & - & - & - \\
\hline SE-2-PB & 80.9 & 37.4 & 82.7 & 38.3 & - & - & - \\
\hline SE-3-Ply-HGB & 280.0 & 70.1 & 16.1 & 4.0 & 29.0 & 1.8 & 94.3 \\
\hline SE-4-Ply-Al & 268.1 & 67.2 & 119.7 & 30.0 & -11.4 & -0.1 & 55.4 \\
\hline SE-5-PB-Al & 93.9 & 21.8 & 64.0 & 14.8 & -11.4 & -0.2 & 31.9 \\
\hline SE-6-PB-HGB 1 & 87.4 & 40.5 & 10.2 & 4.7 & 13.2 & 1.3 & 88.4 \\
\hline SE-7-PB-HGB2 & 107.8 & 27.0 & 12.5 & 3.1 & 8.8 & 0.7 & 88.4 \\
\hline SE-8-PB-HGB3 & 115.3 & 26.7 & 16.2 & 3.7 & 7.8 & 0.5 & 86.0 \\
\hline SE-9-PB-DGP & 109.2 & 25.3 & 9.3 & 2.2 & 9.4 & 1.0 & 91.5 \\
\hline SE-10-PB-WET & 105.6 & 24.5 & 147.3 & 34.2 & -39.0 & -0.3 & -39.5 \\
\hline SE-11-PB-RW & 93.3 & 21.6 & 31.2 & 7.2 & -0.0 & -0.0 & 66.6 \\
\hline SE-12-PB-HPC & 81.9 & 19.0 & 66.5 & 15.4 & -13.7 & -0.2 & 18.7 \\
\hline SE-13-PB-PNT & 103.9 & 24.1 & 27.3 & 6.3 & 2.6 & 0.1 & 73.8 \\
\hline SE-14-PB-GB & 127.1 & 29.5 & 110.6 & 25.6 & -23.7 & -0.2 & 12.9 \\
\hline
\end{tabular}

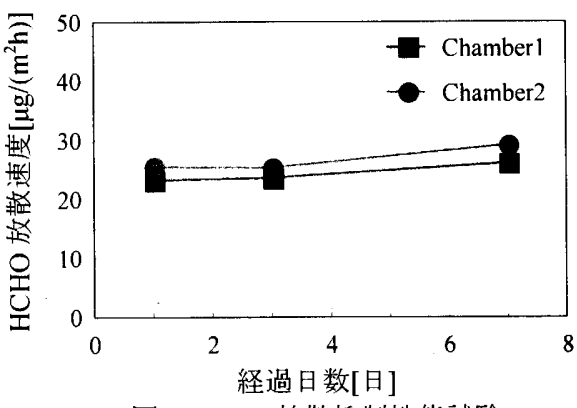

図 3 HCHO 放散抑制性能試験 HCHO 放散建材単体（SE-2-PB）

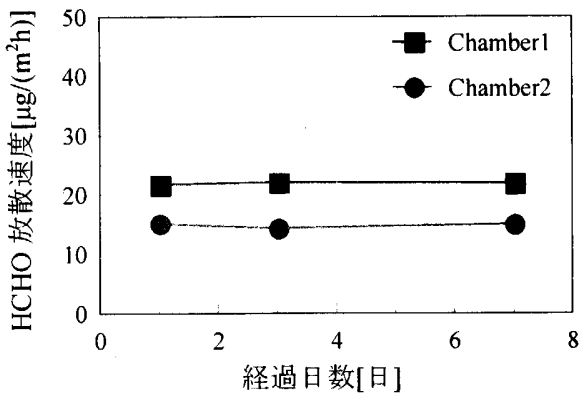

図 4 HCHO 放散抑制性能試験 複合建材（SE-5-PB-Al）

の供給が不要で既存の放散試験用 Test Chamber を使用でき、試験法 もJIS A 1901 に準じた非常に簡便で有用な測定法であることが確認 できた。

表 5 ならびに図 3〜7 に結果を示求。図 $30 \mathrm{HCHO}$ 放散建材単体 (SE-2-PB) では、両 Chamber の放散速度 $E F_{a}$ がほぼ同じであり、 $\mathrm{HCHO}$ 放散抑制性能試験に使用可能な建材であった。

図 3 (SE-2-PB) と図 4 (SE-5-PB-Al) を比較すると、図 4 の $\mathrm{Al}$ をはり合せた場合は狭義の放散抑制性能があるため、Chamber2 の複 合建材の $E F_{a 2}$ が Chamberl の $E F_{a 1}$ よりも小さくなっていることがわ かる。このことから、SE-4-Ply-Al, SE-5-PB-Al の場合（表 5)、狭義 の HCHO 放散抑制性能があることがわかる。しかし、HCHO 放散建 材は $\mathrm{HCHO}$ 放散面積 $(Q / A(=n / L))$ の違いにより、 $\mathrm{HCHO}$ 放散量 が変化するという性質がある文 22.23)。このため、式(1) (4)で求まる Chamber1 の $\mathrm{HCHO}$ 放散建材単体（PB）の $E F_{a 1.1 / 3}$ より、Chamber2 の複合建材 $(\mathrm{PB}+\mathrm{Al})$ の $E F_{a 2.1 / 3}$ が大きくなり、ads や $Q_{\text {ads }}$ は負の值 となる。よって、広義の放散抑制性能（濃度低減性能）がないこと がわかる。本試験法は吸着性能を有するパッシブ吸着建材を対象と

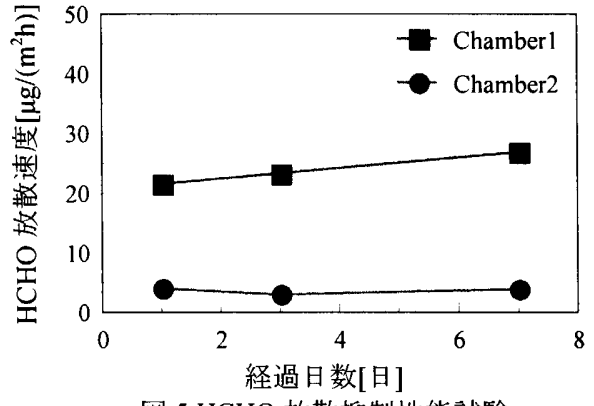

図 5 HCHO 放散抑制性能試験 複合建材（SE-8-PB-HGB3）

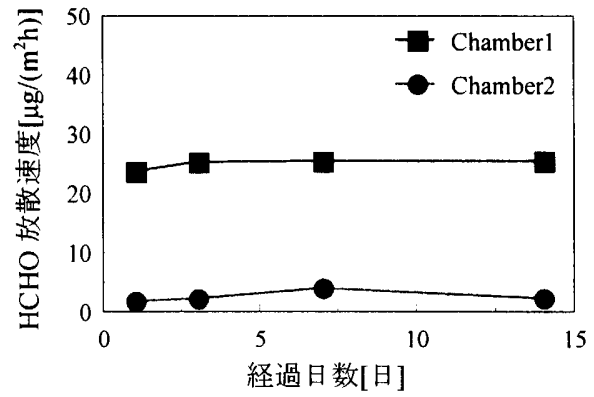

図 $6 \mathrm{HCHO}$ 放散抑制性能試験 複合建材 (SE-9-PB-DGP)

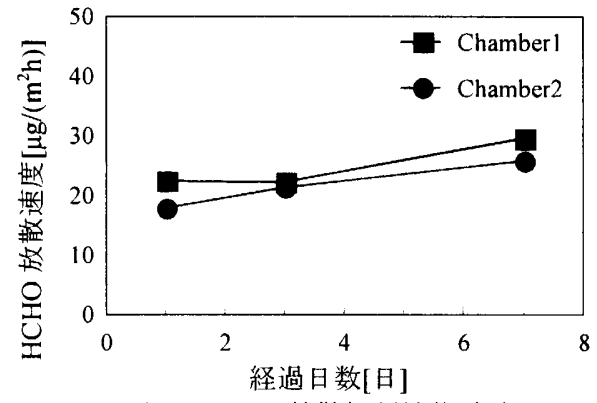

図 $7 \mathrm{HCHO}$ 放散抑制性能試験

複合建材（SE-14-PB-GB）

した試験法である。これより、単に遮蔽効果（シール効果）だけで は、広義の放散抑制性能（濃度低減性能）を過大評価しない試験法 であることが確認できた。

SE-6-PB-HGB1〜SE-8-PB-HGB3 を比べると、 $Q / A(=n / L)$ の変化 によって ads， $Q_{\text {ads }}$ が影響を受けることがわかった（表 5, 図 5)。横 並びの性能評価をするためには、 $Q / A(=n / L)$ を一定とした試験条 件が必要である。SE-9-PB-DGP, SE-10-PB-WET は、湿式材料のパッ 
シブ吸着建材を試験した場合である（表 5, 図 6)。湿式材料を 使用した場合も同様に HCHO 濃度低減性能を評価できること が確認できた。

表 5 の SE-8-PB-HGB3 以降は、 $Q / A=0.23[\mathrm{~m} / \mathrm{h}]$ の条件で試験 を行なった結果である。HGB や DGP は、狭義の $\mathrm{HCHO}$ 放散抑 制性能ならびに広義の放散抑制性能（濃度低減性能）が確認で きた。これは、図 3 (SE-2-PB) と図 5,6を比較しても理解でき る。また、比較建材 GB（SE-14-PB-GB）は、表 5, 図 7 より Chamber1 (PB 単体) と Chamber2 (複合建材: $\mathrm{PB}+\mathrm{GB}$ ) の $\mathrm{HCHO}$ 放散速度がほぼ同じであるので、HCHO 放散抑制性能（狭義と 広義）が見られず、通常の建材は濃度低減性能がないという評 価ができた汭9。一方、SE-10-PB-WET〜SE-13-PB-PNT のパッシ ブ吸着建材は、 $\mathrm{HCHO}$ 放散抑制性能が見られなかった。特に SE-10-PB-WET は、Chamber2 の複合建材の方が Chamber1 の HCHO 放散建材よりも $E F_{a}$ が大きくなってしまった。これは吸着建材と謳 いながら、HCHO が建材成分中に含有されていて、HCHO 放散があ ったことが原因である洋101。

このような建材が市場に流通していることを考えると、本試験法 はパッシブ吸着建材の HCHO 濃度低隇性能試験法の一つとして、有 効性をもつものと考えられる。

\section{2 定常法による HCHO 濃度低減性能試験結果}

定常法試験結果を表 6、図 8〜10 に示す。ADPAC Chamber 内に気 流制御二ニットAD-FLOW を設置した場合、物質伝達率 $\boldsymbol{\alpha}_{m}$ が大きく なるため、SS-1-HGB1 と SS-2-HGB2では明らかに濃度低減性能に 大きな差が生じることが示された。このことから、パッシブ吸着建 材の濃度低減性能試験を行う場合、 $\alpha_{m}$ の影響を考慮した試験が必要 なことが再確認された文12)。SS-2-HGB2 とSS-3-HGB3 では、Q/A（= $n / L)$ が変化すると、 $\mathrm{HCHO}$ 放散抑制性能試験と同様、換気量換算値 $Q_{a d s}$ が変化するので、 $Q / A(=n / L)$ を一定とした条件で試験を行う ことが必要である。

表 6 の $Q / A=0.23[\mathrm{~m} / \mathrm{h}]$ の条件で試験を行なった SS-3-HGB3〜 SS-8-CSB については、HGBや DGP などは HCHO 濃度低減性能が 確認できた。しかし、パッシブ吸着建材と嵒っている CSB は HCHO 濃度低減性能がなかった泪10)。また、RWや HPC は、定常法では濃 度低減性能が確認されたが、放散抑制性能試験では性能がなかった。

SS-9-GB, SS-10-RWR の比較建材は、濃度低減性能がなかった（表 6)。ただし、図 10 に示すように試験初期段階では物理吸着による濃 度低減性能が見られた。

\section{6. 考察}

HCHO 放散抑制性能試験の ads や $Q_{a d s}$ は、負（マイナス）の評価 となってしまう場合がある。これは狭義の放散抑制性能がないため、 はり合せた建材を HCHO が透過すること、Chamber2 での複合建材 の HCHO 放散建材露出面の HCHO 放散速度が Chamberl での放散速 度 $E F_{a 1.1 / 3}$ よりも大きくなることが原因である。ただし、SE-4-Ply-Al や SE-5-PB-Al の場合、Al をはり合せた面は遮蔽されているため、 狭義の放散抑制性能は有するが、複合建材の $\mathrm{HCHO}$ 放散建材面の $\mathrm{HCHO}$ 放散速度が大きくなるために $Q_{a d s}$ が負の評価となる。

HCHO 放散抑制性能試験の HGB (SE-6-PB-HGB1 〜 SE-8-PB-HGB3) の試験結果を比べると、Q/A (=n/L) の変化によっ
表 6 定常法による $\mathrm{HCHO}$ 濃度低減性能試験結果 $\left(28^{\circ} \mathrm{C}, 50 \% \mathrm{RH}\right)$

\begin{tabular}{lcrccc}
\multicolumn{1}{c}{ Case } & $\begin{array}{c}\text { AD- } \\
\text { FLOW }\end{array}$ & $\begin{array}{c}C_{i} \\
{\left[\mu \mathrm{g} / \mathrm{m}^{3}\right]}\end{array}$ & $\begin{array}{c}C_{o} \\
{\left[\mu \mathrm{g} / \mathrm{m}^{3}\right]}\end{array}$ & $\begin{array}{c}a d s \\
{\left[\mu \mathrm{g} /\left(\mathrm{m}^{2} \mathrm{~h}\right)\right]}\end{array}$ & $\begin{array}{c}Q_{\text {ads }} \\
{\left[\mathrm{m}^{3} /\left(\mathrm{hm}^{2}\right)\right]}\end{array}$ \\
\hline SS-1-HGB1 & 有 & 105.2 & 11.9 & 42.3 & 3.6 \\
SS-2-HGB2 & 無 & 99.6 & 26.6 & 33.8 & 1.3 \\
SS-3-HGB3 & 無 & 99.6 & 20.7 & 18.3 & 0.9 \\
SS-4-DGP & 無 & 96.6 & 10.9 & 19.9 & 1.8 \\
SS-5-RW & 無 & 96.4 & 21.5 & 17.4 & 0.8 \\
SS-6-HPC & 無 & 97.6 & 17.4 & 18.6 & 1.1 \\
SS-7-PNT & 無 & 97.2 & 26.3 & 16.4 & 0.6 \\
SS-8-CSB & 無 & 96.4 & 73.4 & 5.3 & 0.1 \\
SS-9-GB & 無 & 97.2 & 88.7 & 2.0 & 0.0 \\
SS-10-RWR & 無 & 97.6 & 92.0 & 1.3 & 0.0 \\
\hline
\end{tabular}

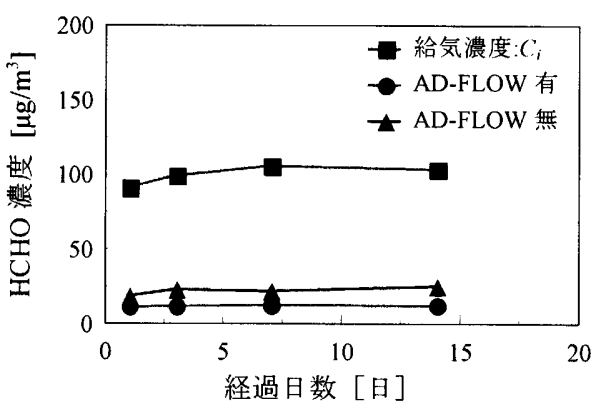

図 8 定常法試験（SS-1-HGB1, SS-2-HGB2）

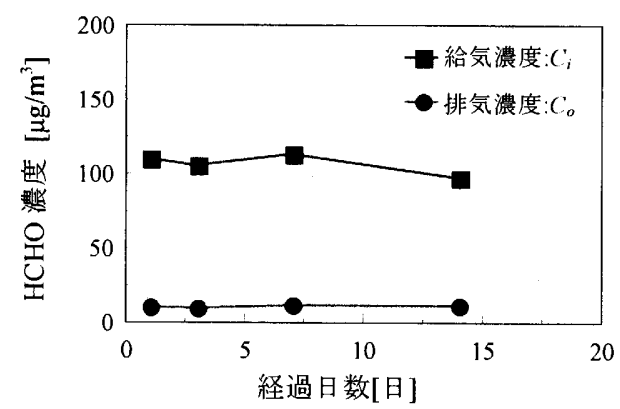

図 9 定常法試験（SS-4-DGP）

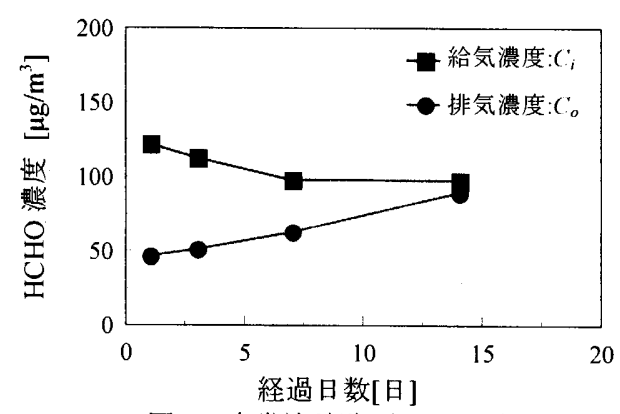

図 10 定常法試験（SS-9-GB）

て ads, $Q_{\text {ads }}$ が影響を受けることがわかる（表 5)。パッシブ吸着建材 の濃度低減性能を横並びに評価するためには、 $Q / A(=n / L)$ を一定 とした試験が必要である。一般的に JIS A 1901 では、 $Q / A(=n / L)=$ $0.23[\mathrm{~m} / \mathrm{h}] \quad\left(n=0.5\left[\mathrm{~h}^{-1}\right], L=2.2\left[\mathrm{~m}^{2} / \mathrm{m}^{3}\right]\right)$ の条件で測定されている。 本試験法でも同一条件で試験を行うことが性能評価が容易と思われ る。また、 $Q_{a d s}$ を換気量確保のための補助的数值として利用する場 合も $Q / A=0.23[\mathrm{~m} / \mathrm{h}]$ の条件は、安全側の評価となることから、設計 者側からも利用しやすいものと考えられる。定常法試験の SS-2-HGB2 と SS-3-HGB3 でも HCHO 放散抑制性能試験と同様、Q/A $(=n / L)$ の変化により $Q_{\text {ads }}$ が変化するので、 $Q / A$ を一定 $(0.23[\mathrm{~m} / \mathrm{h}])$ とした条件で試験を行うことが必要である。 
SE-4-Ply-Al，SE-5-PB-Al では、HCHO 放散面の 2/3 の面積に遮蔽 材を想定して Al をはっている。表 5 の放散抑制率 Sup $2 / 3$ をみると、 それぞれ約 55\%および約 32\%の放散抑制率であり、いずれも $\mathrm{Al}$ で 覆った面積比の 67\%を大幅に下回っている。これは、HCHO を放散 する Ply (合板) やPB (パーティクルボード) の HCHO 放散性状が、 室内空気が低濃度ほど大きくなることに対応し、Chamber2 での HCHO 濃度が Chamberl に比心゙低下したため、その分放散量が増加

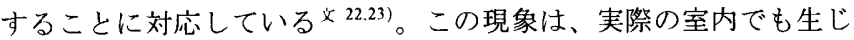
ている可能性がある。今回提案する試験法は、この現象を想定した 試験法となっている。

Al は遮蔽効果によって HCHO の放散を抑制しているが濃度低減 効果はなく、狭義の放散抑制性能しかない。一方、HGB, DGP, PNT などは Sup $2 / 3$ が $67 \%$ 以上と大きいことから、広義の放散抑制性能（濃 度低減性能）を有する。また、SE-14-PB-GBのような比較建材の場 合、Sup $2 / 3$ が 67\%より大幅に小さい。これは、建材中を $\mathrm{HCHO}$ が透 過してしまって狭義の放散抑制性能がないだけでなく、広義の放散 抑制性能もない、すなわち濃度低減性能もないことが原因である。

表 7 に示寸ように、HCHO 放散抑制性能試験の $Q_{\text {ads }}$ の方は定常法 の $Q_{a d k}$ よりも小さな值となるが、両試験法の結果は対応している。 また図 11 から、HCHO 放散抑制性能試験法が定常法よりも安全側 に評価されていることがわかる。これは、HCHO 放散抑制性能試験 の場合、前述したように(1) 複合建材の HCHO 放散面積が $1 / 3$ に減 少するので $E F_{a}$ が大きくなること、(2) 吸着面積も定常法より小さく、 (3) さらに気中からの HCHO 吸着だけでなく建材中を透過してくる $\mathrm{HCHO}$ も吸着しなくてはいけないので、非常に厳しい性能評価とな る。このことは、パッシブ吸着建材の濃度低減性能を安全側に評価 することになる。

表 6 の SS-3-HGB3〜SS-8-CSB をみると、RW や HPC は定常法で は濃度低減性能が確認されたが、HCHO 放散抑制性能試験では性能 が見られなかった。これは表面のみで室内の $\mathrm{HCHO}$ 濃度のみを低減 させようと意図した建材の場合、HCHO 放散抑制性能試験は非常に 厳しい試験となることを示唆している。一般的に住宅内では、壁・ 天井裏など、放散抑制建材をはり付けできない場所が存在し、室内 側一の透過·移流も考えられる。実際、佐藤らや林らは、実大実験住 宅において壁体内から室内側一化学物質が移流や透過することを確

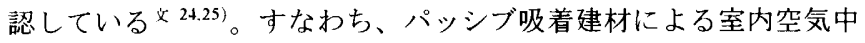
の HCHO 吸着は、壁裏など放散抑制建材をはり付计できない面から 放散される $\mathrm{HCHO}$ にも対志寸ることも当然のことと考えられる。こ の意味で今回提案する HCHO 放散抑制性能試験は、より実現象に近 い試験方法と考えられる。

\section{7. 結論}

パッシブ吸着建材の HCHO 濃度低減性能試験法として、HCHO 放 散抑制性能試験を行った。

1）本試験法は、JIS A 1901 を基本とし、汎用的な 20L 小形 Chamber を使用した簡便で有用な測定法である。

2）本試験法は、パッシブ吸着建材の狭義の放散抑制性能と広義の 抑制性能である室内濃度低減性能を同時に評価するものであり、 実現象に近い試験法である。

3）ボード類のほかに湿式材料についても本試験法が適用可能であ
表 $7 \mathrm{HCHO}$ 放散抑制性能試験法と定常法試験の $Q_{a d s}$ の比較

\begin{tabular}{ccc}
\hline \multirow{2}{*}{ 試験建材 } & \multicolumn{2}{c}{$Q_{\text {ads }}\left[\mathrm{m}^{3} / \mathrm{hm}^{2}\right]$} \\
& 放散抑制 & 定常法 \\
\hline HGB & 0.5 & 0.9 \\
DGP & 1.0 & 1.8 \\
RW & -0.0 & 0.8 \\
PNT & 0.1 & 0.6 \\
HPC & -0.2 & 1.1 \\
GB & -0.2 & 0.0 \\
\hline
\end{tabular}

$Q / A=0.23[\mathrm{~m} / \mathrm{h}]$ の場合

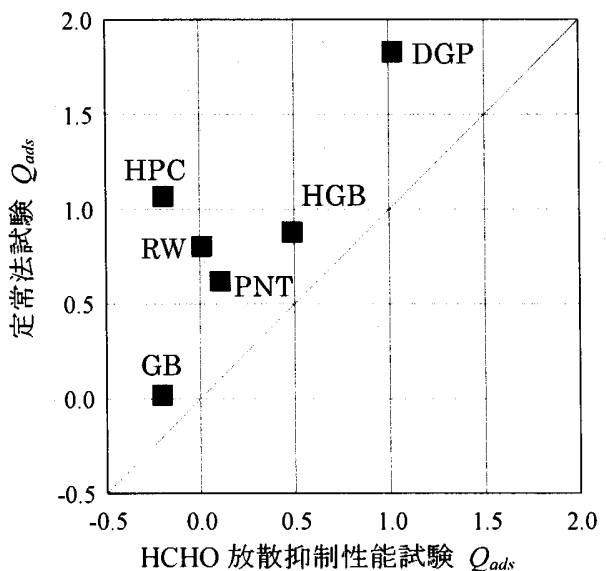

図 $11 \mathrm{HCHO}$ 放散抑制性能試験と定常法試験の $Q_{\text {ads }}$ の関係

ることを確認した。

4）性能評価指標しして用いた換気量換算值 $Q_{a d s}$ は、本試験法と定 常法でほぼ対応しているが、定常法よりも小さかった。これは 安全側の性能評価につながる。

5）気流制御ユニット使用の有無による濃度低减性能の違いを確認 し、パッシブ吸着建材の濃度低減性能試験を行う場合、物質伝 達率 $\alpha_{m}$ が非常に影響することを再確認した。

6）濃度低減性能は $Q / A$ にも影響されるため、20L 小形 Chamber を 使用する場合、横並びの性能評価をするために、放散量測定試 験法と同様の $Q / A=0.23[\mathrm{~m} / \mathrm{h}]$ の条件で試験を行なうことが必要 である。

7）市場流通品の中には、HCHO 濃度低減性能がないパッシブ吸着 建材もあった。このことからも、本試験法の有用性が認識でき る。

8）今後、HCHO 以外の揮発性有機化合物（VOCs）の濃度低減性能 を謳ったパッシブ吸着建材の濃度低減性能試験を行なっていく 予定である。また、濃度低減性能の妨害に関する検討を行なう 必要がある。今後の検討課題である。

\section{謝辞}

本研究は、独立行政法人 新エネルギー・産業技術総合開発機構 （NEDO）の委託を受け、財団法人 建材試験センター内に設置され た「建材からの VOC 等放散量の評価方法に関する標準化委員会 吸 着分解低減化部会 (委員長:加藤信介 東京大学生産技術研究所教 授）」の研究活動の一部として行われている。また、日本建築学会特 別調查委員会・シックハウス問題の解明とヘルシーな居住環境の開 発特別研究委員会 (委員長:村上周三 慶応義塾大学理工学部教授) および国土交通省 建設技術研究開発費補助金·室内化学物質空気污 染の事前評価と健康影響防止技術の開発（研究代表者:加藤信介 東 
京大学生産技術研究所教授）の活動の一環としても実施されたもの である。(有)アドテックならびに(株)エアーグッドには、ADPAC SYSTEM を提供して戴いた。関係各位に深甚なる謝意を表する次第 である。

注

[1] 定常法試験上り求まる吸着速度 $a d s\left[\mu \mathrm{g} /\left(\mathrm{m}^{2} \mathrm{~h}\right)\right]$ おうよ゙換気量換算值 $Q_{a d d}\left[\mathrm{~m}^{3} /\left(\mathrm{hm}^{2}\right)\right]$ は次式となる。

$$
\begin{aligned}
& a d s=\left(C_{i}-C_{O}\right) \cdot Q / A \\
& Q_{a d s}=\left(C_{i} / C_{O}-1\right) \cdot Q / A
\end{aligned}
$$

121 式(2)では、 $E F_{a 1}=E F_{a 1.1 / 3}$ という仮定をしている。これは Chamberl での放 散建材面積の $1 / 3(33 \%)$ 的らの HCHO 放散量（放散速度）が Chamber2 での HCHO 放散量（放散速度）上仮定寸るためである (Chamber2 での $\mathrm{HCHO}$ 放散建材の露出面積は全体の $1 / 3(33 \%)$ である)。

|3| 本研究では、ハッシブ吸着建材が面積比で $2 / 3(67 \%)$ はり合せされてい るのときの放散抑制率であり、はり合せ面積によってこの放散抑制率は 当然変化寸ることに注意が必要である。

[4] 試験体はメ一カー一から直接入手、あるいは建材店上り入手した。メーカ 一から入手の場合、製造直後の製品孝無作為に抽出している。試験体は アルミホイルで包不更にビニル袋で密閉した状態で輸送·保存している。

[5] HCHO 放散量は、試験期間内の放散速度減少が小さい材料を使用するこ とが望ましい。

16]建材表面で釘頭·ねじ頭等が飛び出ていないようにする。釘頭・ねじ頭の 面積は、ハッシブ吸着建材の面積に対し $1 \%$ 以内となる様にした。

[7] 両 Chamber の放散速度が概权同じであることを確認し、高放散量の $\mathrm{HCHO}$ 放散建材を複合建材に用いる。

[8] 本報での AD-FLOW を用いた場合の水蒸気の物質伝達率 $\alpha_{m}$ は $18.7[\mathrm{~m} / \mathrm{h}]$ 程度である文21.21!。通常の ADPAC Chamber $の$ 水蒸気の物質伝達薛は、3.9 $[\mathrm{m} / \mathrm{h}]$ 程度である地。

19]佐藤らは、せっこうボード（GB）の化学物質透過性能が大きいことを報 告している。この大きな透過性能により、両チャンバーの放散速度がは ぼ一致したものと思われる文24。

[10] WET は建材からの HCHO 放散があるため、定常法試験は行わなかった。 CSB は定常法試験で明らかに濃度低減性能が見られなかったことから、 $\mathrm{HCHO}$ 放散抑制性能試験は行な颃なおった。

参考文献

[1]安宅勇二, 加瀬田郎，横山至，加藤信介，村上周三：定常法による $\mathrm{HCHO}$ 吸収分解せっこうボードの濃度低減効果の検乱, 日本建築学会大 会学術講演梗概集 D-2,pp875-876,2001

|2|関根嘉香, 西村厚司: 室内空気中ホルムアルデヒド除去用パッシブ型分解 除去ボードの開発，臭気の研究 Vol.30, No.1, pp39-47, 1999

[3| 柴野一則, 萩原秀彦，小川游：室内空気污染対策に関寸る研究（第 1 報）， 日本建築学会大会学術講演梗概集 D-2,pp869-870,2001

|4| 鈴木昭人，川合秀治，田辺新一：多孔質セラミックス調湿建材に関する研 究，日本建築学会大会学術講演梗概集 D-2,pp995-996, 2002

[5] 下之園孝, 大河原忠義, 半田晋也, 和久井健洋, 堀 雅宏：グラフト重合 高分子塗膜剂索用いる室内環境中ホルムアルデヒド低減方法の検討，日 本建築学会大会学術講演梗概集 D-2, pp975-976, 2003

|6|（財）日本建築セン夕一,新建築技術認定事業 室内空気中の揮発性有機化 合物污染低減建材認定基準 BCJ-BS-5 $5^{-2011}, 2001$

[7] (財)建材試験センター, シックハウス対策JIS $\sigma$ 構造と概要梗概集, 2003

|8| 成富隆昭, 富岡一之, 山口一: 室内濃度域に打けるホルムアルデヒド低 減材の評価，日本建築学会大会学術講演梗概集 D-2, pp859-860,2001

[9] 長谷川麻子, 木村 洋, 小荐裕己, 鎌田元康 : バッシブ型ホルムアルデヒ ド（HCHO）除去製品の簡易性能試験方法，日本建築学会計画系諭文集， No. $548, \mathrm{pp} 57-62,2001.10$

[10]野㠃淳夫，杉野目洋子，景山貴浩：日用污染低減対策品の化学物質除去性 能試験法に関す万研究 (その) 1)，日本建築学会大会学術講演梗概集 D-2, pp953-954, 2003

[11] 桑沢保夫，大澤元毅，岡部 実: ホルムアルデヒドキャッチャ一剤の効果 に関寸る基礎的研究，空気調和・衛生工学会学術講演会講演論文集, pp425-428, 2003

[12]安宅勇二, 加藤信介, 村上周三, 朱 清宇, 伊藤一秀：化学反忘型パッシ ブ吸着建材の濃度低減効果に関する研究 濃度低減効果測定法の開発と 検証第 1 報, 日本建築学会環境系論文集, No.581, pp59-66, 2004.7

[13] JIS A 1901：建築材料の揮発性有機化合物（VOC），ホルムアルデヒド及 び他のカルボニル化合物放散測定方法 - 小形チャンバー法, 2003

[14]村上周三監修：JIS 使い方シリーズ - シックハウス対策に役立つ小形于 ヤンバー法 解説[JIS A 1901], 日本規格協会, 2003

[15] 伊藤一秀, 村上周三, 加藤信介, 近藤靖史, 朱 清宇, 神 卓也：揮発性 有機化合物の放散・吸脱着等のモデリングとその数值予測に関寸る研究
(その 14), 空気調和·衛生工学会学術講演会講演論文集, pp493-496, 1999 |16|朱 清宇, 加藤信介, 村上周三, 伊藤一秀：境界層型小形 Test Chambe の開発上試験建材表面の化学物質伝達率に関する実験と CFD 解析, 日本 建築学会計画系論文集, No.549,pp45-50, 2001.11

[17|安宅勇二, 加藤信介, 朱 清宇, 徐 長厚 : バッシブ吸着建材のホルムア ルデヒド放散抑制性能試験, 日本建築学会大会学術講演梗概集 D-2, pp1017-1020,2004

[18|徐 長厚, 加藤信介,安宅勇二, 朱 清宇: バッシブ吸着建材のホルムアル デヒド放散抑制性能試験（その2），空気調和・衛生工学会大会学術講演 論文集, pp1427-1430,2004

[19]安宅勇二, 加藤信介, 朱 清宇, 徐 長厚 : バッシブ吸着建材のホルムア ルデヒド放散抑制性能試験（その3），日本環境管理学会·室内環境学会 合同研究発表会講演予稿集,pp220-223, 2004

[20]木原生雄, 中川貴文, 田中博, 舟木理香, 田辺新一：小型チャンバー ADPACを用いたアルデヒド類、VOC 放散量の測定に関寸る研究(その 9)， 日本建築学会大会学術講演梗概集 D-2,pp931-932,2003

[21]田中博, 木原生雄, 中川貴文, 舟木理香, 田辺新一：小型チャンバー ADPAC を用いたアルデヒド類、VOC 放散量の測定に関する研究（その 10），日本建築学会大会学術講演梗概集 D-2,pp933-934, 2003

[22]舟木里香，田辺新一，田中 博：建材からのアルデヒド類・VOC 放散速度 測定用小型チャンバーの性能試験及び異なるチャンバー間におけるホル ムアルデヒド放散量の比較, 日本建築学会環境系論文集, No.572, pp47-54 2003.10

〔23|朱 清宇, 加藤信介, 安宅勇二：テストチャンバー実験及び CFD 解析に よる Medium Density Fiberboardにおける物質伝達率が放散速度に与える 影響の検討 一ホルムアルデヒド放散量測定用テストチャンバー法に関 寸る研究一, 日本建築学会環境系論文集, No.582, pp67-74, 2004.8

|24]佐藤重幸，廣川美子，坊垣和明，桑沢保夫，林基哉，近藤誠治：大 形チャンバー内の木造住宅における VOCs の放散性状, 日本建 築学会環境系論文集, No.571,pp75-81, 2003.9

[25]林基哉，大澤元毅: 内部建材の化学物質が室内空気質に与える影 響 第 3 種換気システムを用いた戸建木造住宅に関する基礎実 験，日本建築学会環境系論文集, No.573,pp63-69,2003.11 